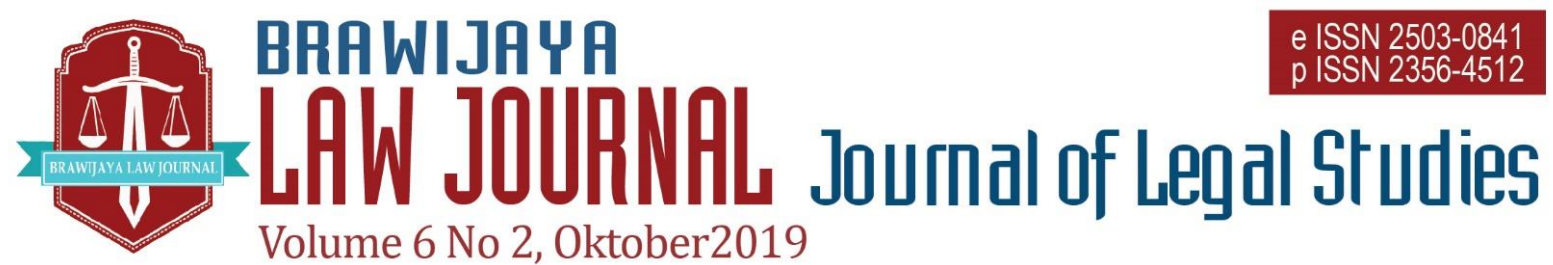

Nationally Accredited No. 30/E/KPT/2018 Dated 24th October 2018

This work is licensed under a Creative Commons Attribution-NonCommercial 4.0 International License

\title{
State Regulation on Business Entities Owned by State Universities: Losses and Liability
}

\author{
Shinta Hadiyantina ${ }^{a}$, Nandaru Ramadhan ${ }^{b}$ \\ a,b Faculty of Law, Universitas Brawijaya \\ Email: shinta_fh@ub.ac.id
}

Submitted : 2019-08-14 | Accepted : 2019-10-30

\begin{abstract}
The Act of Higher Education stated that Higher Education Management Autonomy is carried out by the basis and objectives and abilities of tertiary institutions. This causes not all State Universities to have the same status, one of which is Legal Entity State University. Legal Entity State University is a state university established by the government which is an autonomous public legal entity. Implementing regulations related to Legal Entity State University is Government Regulation Number 26 in 2015 on the Form and Mechanism of Legal Entity State University Funding. The Government Regulation indicates that Legal Entity State University can have a business entity. The problem is, if the Legal Entity State University carries out a business activity, there will be a possibility that the business will suffer losses. If there is a loss, how is the liability for the loss of the Legal Entity State University?

Based on the business judgment rule doctrine, not every business loss is classified as a state loss. If the financial loss is not caused by intentional acts against the law or abuse of authority, then that matter is not classified as a state loss. If the losses included state losses, then the liability losses caused by the activities of those business entities owned by state universities are carried out in three ways, there are criminal liability, civil liability, and accountability in the state administrative law.
\end{abstract}

Keywords: legal entity state university; business entities owned by state universities; losses; liability

\section{INTRODUCTION}

Common goals or ideals determine the upholding of the constitution and constitutionalism in a country because it is the shared ideals that at the peak of their abstraction most likely reflect the similarities of interests among fellow citizens who in reality must live aid of diversity or pluralism. Therefore, in a society, to guarantee togetherness in the framework of state life, it is necessary to formulate common goals or ideals which are also referred to as state philosophy or staatsidee (state ideals) which function as filosofische grondslags and 
common platforms or kalimatun sawa among fellow citizens in the context of state life. ${ }^{1}$

In Indonesia, the intended philosophical foundations are commonly referred to as Pancasila, which means five precepts or five basic principles for achieving or realizing the four goals of the state. The five basic principles of Pancasila include principles or (i) Believe in the One and Only God, (ii) Just and Civilized Humanity, (iii) The Unity of Indonesia, (iv) Democratic rule that is guided by the strength of wisdom resulting from Deliberation/Representation, and (v) Social justice for all the people of Indonesia. These five precepts are used as a philosophical-ideological basis for realizing the four goals or ideals of the ideal of the state, namely: (i) to protect the whole people of Indonesia and the entire homeland of Indonesia, (ii) to advance general prosperity, (iii) to develop the nation's intellectual life, and (iv) to contribute in the implementation of a world order based on freedom, lasting peace, and social justice. ${ }^{2}$ The administration of government in Indonesia is essential to fulfilling the mandate contained in the Preamble of the 1945 Constitution of the Republic of Indonesia (hereinafter referred to as the 1945 Constitution), in the fourth paragraph.

The notion of governance can be understood through two meanings: on the one hand in the sense of "governmental function" (governing activities), on the other hand in the sense of "governmental organization" (a set of governmental

1 Jimly Asshiddiqie, Konstitusi Bernegara: Praksis Kenegaraan Bermartabat dan Demokratis, (Malang: Setara Press, 2015), p. 57.

2 Ibid, p. 58.

3 Philipus M. Hadjon dkk., Pengantar Hukum Administrasi Indonesia (Introduction to The Indonesian Administrative Law), (Yogyakarta: Gadjah Mada University Press, 2008), p. 6

4 Muhammad Rakhmat, 2014, Hukum Administrasi Negara Indonesia, Journal of Majalengka entities). The function of government (executive) can be formulated negatively as all sorts of activities of the authorities which cannot be mentioned as a regulatory (legislative) or judiciary (judicial) activity. ${ }^{3}$ This is in line with the residual theory of Van Vollenhoven in his book "Omtrek Van Het Administratief Recht", which divides government power or functions into four functions namely function of governing (bestuur), function of policy (politie), function of adjudicating (justitie), and function of regulating (regelaar). The function of governing in a modern state has a very broad task, not only limited to the implementation of laws. The government has interfered in matters of community life in the economic, socio-cultural, and political fields. ${ }^{4}$

In the conception of the modern state of law (welfare state, verzorgingsstaat), the government has a responsibility to maintain general welfare (bestuurszorg). On the other words, the task and function of the government is to regulate (regelen) and manage (besturen) the works on administration and to serve public order (Algemeen belang). ${ }^{5}$ This function of the government is run by the government to carry out the State's idea, i.e. to protect the whole of Indonesia and the entire homeland of Indonesia, to improve general welfare, to advance intellectual life, and to participate in the world order. ${ }^{6}$

Education is one of the government affairs that must be held by the government.

University, accessed on 5 March 2018, from jurnal.unma.ac.id/index.php/RBJ/article/downloa d/531/495, p. 55.

5 Ridwan, Tiga Dimensi Hukum Administrasi dan Peradilan Administrasi, (Yogyakarta: FH UII Press, 2009), p. 37.

6 Paragraph 4 of the Preamble of the Constitution of the Republic of Indonesia in 1945. 
Education is considered so important that the law requires $20 \%$ of the total State Budget $(\mathrm{APBN})$. To regulate the implementation of education, the government issued Act Number 20 in 2013 on the National Education System (hereinafter referred to as the National Education System Act). This law is a renewal of the previous National Education System Act, namely Act Number 2 the Year 1989 on the National Education System. Act Number 2 the Year 1989 on the National Education System is deemed inadequate and needs to be replaced and needs to be refined to conform the mandate amending in the 1945 Constitution of the Republic of Indonesia.

The National Education System Act states that "National education functions to develop capabilities and shape the dignified character and civilization of the nation in the context of educating the life of the nation, aiming at developing the potential of learners to become human beings who believe and have faith in God Almighty, have good morality, be healthy, knowledgeable, competent, creative, independent, and become democratic and responsible citizens". 7 This act also regulates the rights and obligations of citizens, parents, the community and the government in administering the national education system. These rights and obligations are presented in the Table Rights and Duties of Citizen, Parents, Community, and Government in Organizing National Education System.

Table Rights and Duties of Citizen, Parents, Community, and Government in Organizing National Education System ${ }^{8}$

\begin{tabular}{|c|c|c|c|}
\hline Citizen & Parent & Community & Government \\
\hline $\begin{array}{l}\text { Right to get a good } \\
\text { education }\end{array}$ & $\begin{array}{l}\text { Right to choose } \\
\text { education units, and to } \\
\text { obtain information on }\end{array}$ & $\begin{array}{l}\text { Right to participate in } \\
\text { the planning, executing, } \\
\text { and monitoring process }\end{array}$ & $\begin{array}{l}\text { Right to direct, guide, } \\
\text { support, and supervise } \\
\text { the organization of }\end{array}$ \\
\hline $\begin{array}{l}\text { Right to get education for } \\
\text { the entire of his life }\end{array}$ & $\begin{array}{l}\text { the development of } \\
\text { their children }\end{array}$ & $\begin{array}{l}\text { of the education } \\
\text { program. }\end{array}$ & $\begin{array}{l}\text { education according to } \\
\text { the legislation. }\end{array}$ \\
\hline
\end{tabular}

Right to special

education, for:

. Those handicapped in physical, emotional, mental, intellectual, or social

. Those in a remote area, as well as that, belong to the indigenous community

\footnotetext{
${ }^{7}$ Article 3 of the Act Number 20 Year 2013 on National Education System.
}

\footnotetext{
${ }^{8}$ Article 5-11 of the Act Number 20 Year 2013 on National Education System.
} 
Must attend basic Responsible to provide education (age 7-15)

Be responsible to ensure the implementation of education. basic education to his children according to the age
Responsible to provide materials support in the organization education
Responsible to provide service and access, as well as ensure the organization of good education.

Responsible education

source: Primary data, processed, 2019.

The Act of National Education System divides education paths into 3, namely formal education, non-formal education, and informal education. ${ }^{9}$ The level of formal education consists of elementary education, secondary education, and higher education. ${ }^{10}$ Basic education is in the form of Elementary School (SD) and Madrasah Ibtidaiyah (MI) or other equivalent forms, as well as Junior High Schools (SMP) and Madrasah Tsanawiyah (MTs), or other equivalent forms. ${ }^{11}$ According to Act Number 23 in 2014 on Regional Government, basic education is under the authority of the district/cityregional government. Secondary education consists of general secondary education and vocational secondary education. Secondary education is in the form of Senior High School (SMA), Madrasah Aliyah (MA), Vocational High School (SMK), and Vocational Aliyah Madrasah (MAK), or other equivalent forms. ${ }^{12}$ According to Act Number 23 Year 2014 on Regional Government, secondary education is the authority of the provincial regional government. Higher education is the last level of education, right after secondary education, that includes diploma, undergraduate, master's, specialist, and doctoral education programs organized by tertiary institutions. Colleges can be in the form of academies, polytechnics, high schools, institutes, or universities. ${ }^{13}$ The authority to regulate higher education is regulated by the minister.

The existing problem with this Act is Article 53, which regulates the Education Legal Entity. This article consists of 4 paragraphs, which in essence is mandatory for all formal education providers and/or units established by the Government or the community in the form of educational legal entities. Article 53 paragraph (4) also mandates that a law related to the Education Legal Body be established. The intended law was passed in 2009, namely Act Number 9 Year 2009 on Educational Legal Entities (hereinafter referred to as BHP Act).

The rationale for the need to establish Act Number 9 Year 2009 on Legal Entity of Education (BHP Act) is closely related to the principle of broad autonomy in the administration of higher education in

\footnotetext{
Article 13 Paragraph (1) of the Act Number 20 Year 2013 on National Education System.

Article 14 of the Act Number 20 in 2013 on National Education System.

Article 17 Paragraph (2) of the Act Number 20 in 2013 on National Education System.

Article 18 Paragraph (3) of the Act Number 20 in 2013 on National Education System.

13 Article 19-20 of the Act Number 20 in 2013 on National Education System.
} 
tertiary institutions. The rationale in question is as follows ${ }^{14}$ :

1. To be able to realize the functions and objectives of national education based on the 1945 Constitution of the Republic of Indonesia, implemented based on the autonomy of higher education in a higher educational institution;

2. The autonomy of higher education can only be realized if the implementation of higher education in the form of legal entity functions to provide fair and good services to students, non-profit principles, and can manage funds independently to advance national education. Thus the BHP Law was formed.

Furthermore, in the clarification of the BHP Law, it is explained that the regulation of educational legal entities is an implementation of state responsibility and is not intended to reduce or avoid state constitutional obligations in the field of education to burden the community and/or students. ${ }^{15}$ The content of the lawsuit over the BHP Law was submitted by the judicial review to the Constitutional Court in 5 lawsuits.

The Constitutional Court unanimously declared the BHP Law unconstitutional. All the contents of this Law are automatically become 'null' and have no binding legal force. The Constitutional Court considered the BHP Law had removed the duties and responsibilities of the Government in the field of education. "With the BHP Law, the

14 Serian Wijatno, Pengelolaan Perguruan Tinggi Secara Efisien, Efektif, dan Ekonomis: Untuk Meningkatkan Mutu Penyelenggaraan Pendidikan dan Mutu Lulusan, (Jakarta: Penerbit Salemba Empat, 2009), p. 30.

15 Id formal education mission which is the duty of the government in Indonesia will be carried out by the Government's Educational Legal Entity (BHPP) and the Regional Government's Educational Legal Entity (BHPPD)." However, the 1945 Constitutional made clear that the responsibility of organizing education is mainly given to the State. ${ }^{16}$

The BHP Law makes BHPP and BHPPD a determinant of educational success. That results in no guarantee of not achieving national education goals while at the same time creating legal uncertainty. If BHPP and BHPPD are unable to carry out their duties, they can be bankrupt. If it is already bankrupt, the state will not assume responsibility. According to the Constitutional Court, the BHP Law makes national education fully submitted to the market mechanism without any protection at all. For example, Article 57 letter $b$ of the BHP Law allows a BHP to be declared bankrupt. The BHP bankruptcy proceedings are subject to Act Number 37 Year 2004 on Bankruptcy and Suspension of Debt Payment Obligations. For the Constitutional Court, it shows the BHP Law does not provide any protection at all from the threat of bankruptcy. ${ }^{17}$

The principle of non-profit in the BHP Law is also questionable. The Court revealed, "That there is a difference between nonprofits and affordable education costs where the latter is a problem in our national education." The principle of non-profit does not automatically make education cheap for students. According to
16 Dny, MK Batalkan UU Badan Hukum Pendidikan, (31 March 2010, Hukum Online), accessed http://www.hukumonline.com/berita/baca/lt4bb 37a39de6cc/mk-batalkan-uu-badan-hukum- pendidikan on 17 April 2018
17 Id.


the Constitutional Court, whether or not the cost of education is determined by various factors. The BHP Law limits the portion of funding from students, a maximum of $1 / 3$ of operational costs. But unfortunately, the definition of operational costs itself is formulated openly and not limited. As a result, the number of operational costs will be determined by the variable costs used in the education process. ${ }^{18}$

The Constitutional Court stated that the BHP Law contradicted the constitution and stated that the Act had no binding legal force. However, the Constitutional Court did not cancel the article on the autonomy of higher education, namely Article 53 of Act Number 20 year 2003 on the National Education System (Law on National Education System). The Court believes that as long as the educational legal entity is defined as the function of the education provider which means that an educational institution must be managed by a legal entity, article 53 (1) is still by the corridor of the 1945 Constitution. ${ }^{19}$

This is what distinguishes Educational Legal Entities from Legal Entity State University (also referred to as PTN-BH). Act Number 12 Year 2012 on Higher Education (the Higher Education Act) continues to provide the principle of autonomy for tertiary institutions, while still considering the ability of tertiary institutions. So, not all state universities are legal entities. Article 62, paragraph (1) and

18 Id.

19 Id.

20 Article 62 Paragraph (1) and (2) of the Law Number 12 in 2012 on Higher Education (State Gazette in 2012 Number 158, Appendix to State Gazette of the Republic of Indonesia Number 5336)

21 News from Dikti's Website, 11 PTN-BH Didorong Meningkatkan Penelitian dan Inovasi, (4 January 2017, Coordination of Private Universities Region XII), accessed at
(2) of the Higher Education Law, states that: ${ }^{20}$

(1) Universities have the autonomy to manage their institutions as a centre for the implementation of Tridharma Perguruan Tinggi.

(2) The autonomy of Higher Education management as referred to in paragraph (1) shall be carried out by the basis and objectives and capabilities of the Higher Education.

Article 62 paragraph (2) of the Higher Education Law states that the Autonomy of Higher Education Management is carried out by the basis and objectives and abilities of tertiary institutions. This causes not all state universities to be state legal entities. Until now, there are eleven Universities that become Legal Entity State Universities (PTN-BH), namely the Bandung Institute of Technology, Bogor Institute of Agriculture, Gadjah Mada University, University of Indonesia, Indonesian University of Education, University of North Sumatra, Airlangga University, Padjajaran University, Diponegoro University, Hasanuddin University, and November 10 Technology Institute. ${ }^{21}$

Legal Entity State Universities (PTN$\mathrm{BH})$ is a state university established by the Government which is an autonomous public legal entity. ${ }^{22}$ Legal Entity State Universities (PTN-BH) have authority that is not owned by State University in general, including: ${ }^{23}$

http://www.kopertis12.or.id/2017/01/05/12-ptnbh-didorong-meningkatkan-penelitian-daninovasi.html on 18 April 2018

22 Article 1 Number (3) of the Government Regulation Number 26 year 2015 on the Form and Mechanism of Funding for Legal Entity State University (State Gazette year 2015 Number 110, Appendix to State Gazette of the Republic of Indonesia Number 5699)

23 Article 25 of the Government Regulation Number 4 year 2014 on the Organization of 
a. Autonomy in the academic field, namely the offering, changing, and closing of study programs;

b. Autonomy in the field of organizational implementation, namely

Determination of organizational structure and work procedures, and (2) Internal control and supervision systems;

c. Autonomy in finance, namely

Short-term and long-term budget planning and management,

Determination of tariffs for each type of education service, (3) Receipt, expenditure, and money management,

(4) Making short-term and long-term investments, and (5) Short and long term debt and receivables.

d. Autonomy in the power sector, namely

(1) Requirements and Procedures for Accepting Human Resources, and (2) Termination of Human Resources

e. Autonomy in the field of facilities and infrastructure, namely the ownership of facilities and infrastructure.

Implementing regulations related to Legal Entity State Universities (PTN-BH) made by the government are Government Regulation Number 26 the Year 2015 on the Form and Mechanism of Legal Entity State University Funding. The Government Regulation indicates that Legal Entity State Universities (PTN-BH) can have a business entity (enterprise). Article 11 paragraph (1) states that "Legal Entity State University Funding sourced from other than the state budget and income, might be sourced from a) the community; b) tuition fees; c) management of endowments; d) Legal

Higher Education and the Management of Universities (State Gazette the year 2014 Number 16, Appendix to State Gazette of the Republic of Indonesia Number 5500)

24 Article 11 paragraph (1) of the Government Regulation Number 26 year 2015 on the Form
Entity State University's enterprise; e) Collaboration of Tridharma Perguruan Tinggi; f) management of Legal Entity State University's assets; g) regional income and expenditure budget; and h) loans." ${ }^{24}$ The following paragraph states that "The Business owned by Legal Entity State Universities (PTN-BH) as referred to in paragraph (1) letter $\mathrm{d}$ is a service supporting the Tridharma Perguruan Tinggi." 25

The problem is, if Legal Entity State Universities (PTN-BH) carries out a business activity, there will be a possibility that the business will suffer losses. No laws and regulations are governing that matter. From the background above, the authors are interested in examining the associated losses caused by business entities of state universities as legal entities and their responsibilities.

\section{LEGAL MATERIAL AND METHODS}

This research was compiled based on normative legal research. Normative legal research is a legal study that focuses on studies of existing laws and regulations, jurisprudence, and legal doctrines. The focus of this research is related to the state losses caused by the loss of business entities of the Legal Entity State Universities (PTN$\mathrm{BH})$ and the responsibility of the Legal Entity State Universities (PTN-BH) for losses caused by the activities of the Legal Entity State Universities (PTN-BH)'s Business units.

The approach used in this research is the statutory approach and conceptual approach. Based on its binding strength,

and Mechanism of Funding for Legal Entity State University

25 Article 11 paragraph (1) of the Government Regulation Number 26 the year 2015 on the Form and Mechanism of Funding for Legal Entity State University 
legal materials can be grouped into primary legal materials and secondary legal materials. The legal material used in this study is the legislation related to the liability of the Legal Entity State University for the Losses of its Enterprise. The legal material used in this study is in the form of all legal publications that do not include official documents, such as textbooks, journals, and opinions of scholars. The publication is a clue or explanation of primary legal material.

The technique used for the legal material collection was in the form of the study of literature that is looking for or finding, reading, understanding, and gathering legal materials following the problems examined in this study. To obtain legal materials that are following the quality used in this study, a search is carried out to find legal materials that are relevant to the legal issues being investigated. The legal materials that have been obtained were then recorded, edited, studied, and then taken its essence in the form of theories, ideas, concepts, proposals of argumentation, and related legal provisions. Furthermore, the legal materials were collected and compiled and grouped according to the problem to be examined. Processing of legal materials was preceded by conducting a selection of legal materials that have been collected, both primary and secondary legal materials. Then the legal materials are selected and sorted according to the needs that will be used to analyze and explain legal problems.

The analysis was prescriptive, i.e. analyzing the collected legal materials by linking with the objectives of the law, the values of justice, the validity of the rule of law, legal concepts, and existing legal norms. The use of prescriptive analysis is expected to find out what the law is and what the norms should be.

\section{RESULT AND DISCUSSION Losses of Legal Entity State Universities' Enterprises as State's Losses}

The main mission of Higher Education is to seek, find, disseminate, and uphold the truth. In order for this mission to be realized, University as the organizer of Higher Education must be free from any influence, pressure, and contamination such as political power and/or economic power, so that the application of Tridharma Perguruan Tinggi, namely education, research, and community service, can be carried out based on academic freedom and scientific autonomy. Therefore, Higher Education has autonomy or independence, both academically and non-academically.

If Higher Education autonomy is the nature of higher education, the State is responsible for protecting and guaranteeing that nature through the stipulation of various laws and regulations, including Government Regulations on the Form and Mechanism of Institutional Higher Education Funding, namely Government Regulation Number 26 the Year 2015 on Form and Mechanism of Funding for Legal Entity State Universities.

The Government Regulation on the Form and Mechanism of Funding for Legal Entity State University is mandated by Article 89 paragraph (3) of Law Number 12 the Year 2012 on Higher Education, which states that the provisions regarding the form and mechanism of Funding for Legal Entity State Universities are regulated by Government Regulation. This government regulation regulates several matters, including:

1. Source of fund funding;

2. Mechanism of funding; and

3. Accountability of Legal Entity State Universities. 
Legal Entity State Universities' Funding based on Government Regulations on the Form and Mechanism of Funding for Legal Entity State Universities comes from three sources, namely:

1. State's Revenue and Budget (Article 3 paragraph (1));

2. Regional Revenue and Budget (Article 3 paragraph (6));

3. Other Sources (Article 3 paragraph (2)).

Other sources as mentioned in Article 3 paragraph (2) of the Government Regulation on the Form and Mechanism of Funding for Legal Entity State Universities consist of:

1. Community;

2. Tuition Fee;

3. Management of endowment fund and Legal Entity State Universities' enterprises;

4. The collaboration of Tridharma;

5. Management of State's treasure which granted by State government and regional government for the development of universities; and/or

6. Other legal sources.

In a graphic, the source of funding for Legal Entity State Universities is presented in the Figure Funding for Legal Entity State Universities.
Figure Funding for Legal Entity State Universities

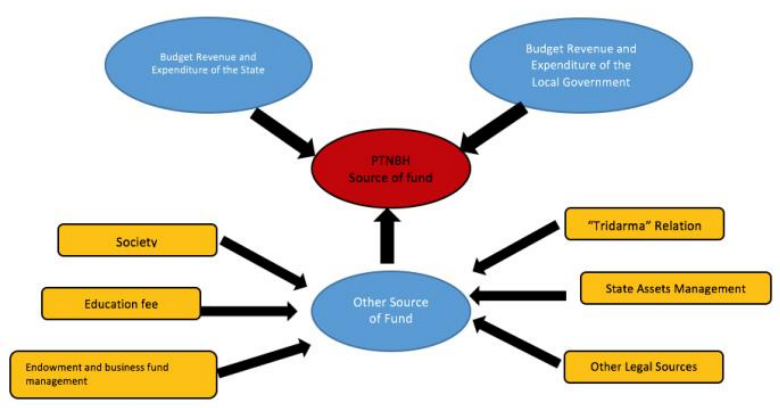

One source of funding for Legal Entity State Universities is from the management of endowment fund and the Legal Entity State Universities' enterprises, which are classified in one of six other sources. The definition of the endowment fund is not explained in the Government Regulation on the Form and Mechanism of Funding for Legal Entity State Universities and Higher Education Law. Eugenio M. Gonzales stated that an endowment fund is a collection of funds managed by an institution for social purposes determined by the donor of funds (donors) and administrators of the institution. These funds are expected to remain intact forever, for a certain period, or until sufficient assets are collected to carry out the specified program. The purchasing power of the endowment fund is expected to become greater over time and can provide regular income throughout the life of the institution. $^{26}$

In many cases, an endowment fund is felt to bring great benefits to the institution because it provides a secure income base, which can partially reduce the pressure to find principal capital, reduce dependence on certain sources of funding, and facilitate

Consultation on Economy and Social (LP3ES), 2004), p. 5-6

${ }^{26}$ Eugenio M. Gonzales, Membentuk dan Mengelola Dana Abadi: Pelajaran dari Asia Tenggara, (Jakarta: Institute of Research, Education, and

242 | Hadiyantina, Ramadhan - State Regulation on Business Entities Owned by State Universities... 
long-term financial planning.

Institutionally, an endowment fund can create a strong feeling that strengthens institutions and all stakeholders, increases concentration to achieve long-term program goals, and maintains program flexibility to achieve these goals. ${ }^{27}$

Although endowment fund can offer a variety of benefits, each institution needs to consider whether an endowment is indeed the right strategy to meet its financial and social mission needs. Raising endowments may be too expensive for certain institutions and also time-consuming. This process requires particular attention and expertise that the institution may not have, both on staff and the board. If given by another institution, the endowment may be subject to various restrictions and rules that must be met by the recipient institution, which may be difficult to follow continuously. Moreover, endowments may not immediately meet the organization's expectations for revenue. Sluggish economies or countries with weak philanthropic cultures can make it difficult to raise endowments. Besides, in certain situations, it may be difficult to convince potential donors, so we should save for tomorrow when there are so many needs today. The fact that the endowment promises a tempting convenience but also contains problems, makes the experience in raising and managing the endowment becomes very important to be understood further. ${ }^{28}$

An example of an endowment fundraiser undertaken by a Legal Entity State University is the University of Indonesia Endowment Fund (Dana Abadi UI). Dana Abadi UI is a fundraising program, where the funds collected will be managed (invested) optimally by Bank BNI and the investment returns will be utilized to help the development of education and learning that takes place at UI. Funds collected from donors will be managed by Bank BNI and part of the proceeds will be submitted to UI to finance educational activities and learning processes, including the development of educational facilities (books, libraries, laboratories, computers, etc.), financing of physical facilities (buildings and facilities others), scholarships (for high-achieving and / or underprivileged students, teaching staff, employees), and partly for entrants / fund owners. $^{29}$

In addition to the source of funds originating from the management of endowment funds, Legal Entity State Universities can also obtain income from the Legal Entity State Universities' enterprises. Establishing a business entity is one of the autonomy owned by a Legal Entity State Universities, as stated in Article 65 paragraph (3) of Law Number 12 the Year 2012 on Higher Education. The article states that Legal Entity State Universities as referred to in paragraph (1) have:

1. Initial capital in form of separate State's treasury other than land;

2. Independent management and decision-making process;

3. A unit that runs accountability and transparency function;

4. Right to manage the fund in an independent, open, and accountable way;

5. Authority to recruit and dismiss lecturer and other educational staff;
${ }^{27} \mathrm{Id}$.

${ }^{28} \mathrm{Id}$.
${ }^{29}$ https://www.ui.ac.id/beranda-alumni/danaabadi.html accessed on 2 July 2019 at 16.00 
6. Authority to establish enterprises and develop endowment fund; and

7. Authority to offer, organize, and close a study program.

This article gives Legal Entity State Universities the authority to establish business entities/enterprises. Article 11 paragraph (2) Government Regulation on the Form and Mechanism of Funding for Legal Entity State Universities states that the enterprises owned by Legal Entity State Universities as referred to in paragraph (1) letter $\mathrm{d}$ is services that support Tridharma Perguruan Tinggi. According to the elucidation of Article 11 paragraph (2), services that support Tridharma Perguruan Tinggi are the implementation of activities of which produce education, research, and community service for the purpose of improving the quality and service of Legal Entity State Universities, as well as to obtain additional fund for the Legal Entity State Universities.

The ability to obtain funds is one of the requirements that must be met so that University can obtain a position as a Legal Entity State Universities. This requirement is regulated in Minister of Education and Culture Regulation Number 88 the Year 2014 on the Change of State Universities into Legal Entities State Universities. These requirements are regulated in Article 2 paragraph (1) of the Minister of Education and Culture Regulation Number 88 the Year 2014 on the Changing of State Universities into Legal Entity State Universities, which states that the Condition to be met by State University to become Legal Entity State Universities include the level and degree of ability of the university to:

1. Apply aqualified Tri Dharma Perguruan Tinggi activities;
2. Run the University's organization based on good organizational management principles;

3. Meet the minimum standard of financial feasibility;

4. Perform social responsibility; and

5. Take part in the development of the economy.

In point $\mathrm{c}$, the minimum standard of financial feasibility is one of the requirements for State universities to become a Legal Entity State Universities. Financial feasibility is further elaborated in Article 2 paragraph (4) of the Minister of Education and Culture Regulation Number 88 the Year 2014 on the Change of State Universities into Legal Entities State Universities. Financial feasibility is assessed from:

1. Management of finance and asset according to the legislations

2. The finance report is assessed as Normal without Question for 2 (two) ins in a row; and

3. Able to raise funds other than from tuition fee from the students.

The ability to raise funds must also be demonstrated in the requirements document that must be met by state universities. There are 4 (four) documents that become the requirements, namely 1 ) self-evaluation of the university; 2) Long-term Development Plan as Legal Entity State Universities; 3) Draft Statute for Legal Entity State Universities; 4) Transfer Plan into Legal Entity State Universities. The ability to raise funds must be demonstrated in document number 2, the Long Term Development Plan as Legal Entity State Universities. Long-term Development Plan of Legal Entity State Universities as 
referred to in Article 3 letter b at least contains:

1. The Background that states rationale and context in the transformation from state university into Legal Entity State University based on the result of the university's self-evaluation;

2. Mandate, Vision, Mission, dan objectives as a Legal Entity State University;

3. System the Guarantee the Internal Quality as a Legal Entity State University;

4. Implementation and development in academic fields that cover Tridharma Perguruan Tinggi in the Legal Entity State University, i.e. Educational Field, Research Field, and Community Service Field;

5. Implementation and development of non-academic fields in Legal Entity State Universities, i.e. Organization and Management Field of the Legal Entity State University, Management and Development of Human Resource Field of the Legal Entity State University;

6. Implementation and development of Student Affair field in the Legal Entity State Universities, i.e. intra-curricular and extra-curricular units for students' activity, student organization, and development of students' talent and interest.

7. Accountability system for Legal Entity State Universities;

8. Risk analysis in the transformation process from state university into Legal Entity State University; and

9. Long-Term Development Plan Phase and Program's Performance Indicators.

Point 5 of the Legal Entity State Universities' Long-Term Development Plan is the organization and development of non-academic fields in the Legal Entity State Universities. The implementation and development of non-academic fields in Legal Entity State Universities consist of 2 parts, namely the organization and governance of Legal Entity State Universities, and the management and development of Legal Entity State Universities' resources. The field of management and development of Legal Entity State Universities' resources consists of human resources, facility and infrastructure resources, financial resources, and information resources. Financial resources set condition of financial resources that must be met are 1) short-term and long-term budgets; 2) rates for each type of education service; 3) receipts, expenditures, and financial management; 4) short-term and long-term investments; 5) business unit development; 6) agreements with third parties within the scope of Tridharma Perguruan Tinggi; 7) short-term and long-term loans and receivables; and 8) financial recording and reporting system. Point 5 of financial resources is the development of business units.

Legal Entity State University has the authority to establish business units and develop endowments. Business units established by Legal Entity State Universities are the same as business units run by other entities, so there is a possibility of loss. The question is what if the business entity established by Legal Entity State Universities experience loss? Are these losses can be classified as state's losses or not? The next question is, if a loss occurs, what kind of responsibility should be given to the loss? Question number two will be explained in the second part of this chapter.

Based on Article 1 paragraph (1) of Act Number 17 the Year 2003 on State 
Finance, it is explained that the definition of state finance is "all rights and obligations of the state that can be valued in money, as well as everything in the form of money or in the form of goods that can be used as state's property related to the implementation and the obligation." Based on the Law on State Finance, state finance can be viewed from four sides. Those sides are the object side, the subject side, the process side, and the goal side. The explanation is as follows ${ }^{30}$ :

1. On the object side, what is meant by state finance includes all state rights and obligations that can be valued in money, including policies and activities in the fiscal, monetary, and management of separated state assets, as well as everything in the form of money, or in the form of goods that can be claimed as state's property in connection with the implementation of the above mentioned rights and obligations.

2. On the subject side, what is meant by state finance is all the objects as mentioned above which are owned by the state, and / or are controlled by the central government, regional governments, state / regional companies, and other bodies related to state finance;

3. In the process side, state finance covers the entire set of activities related to object management as mentioned above, starting from policy formulation and decision making to accountability;

4. In the objective side, state finance includes all policies, activities, and legal relations relating to the ownership and / or control of objects as mentioned

30 Ardeno Kurniawan, Korupsi di Indonesia: Keuangan Negara, Birokrasi dan Pengendalian above in the context of the administration of state government.

Article 2 of the Act on State Finances explains the types of state finances. Types of state finances include ${ }^{31}$ :

1. The right of the state to collect taxes, issue and circulate money, and enforce loans;

2. The obligation of the state to carry out public service tasks of the government of the country and pay bills of third parties;

3. State revenue;

4. State expenditure;

5. Regional income;

6. Regional expenditure.

7. State assets / regional assets that are managed by themselves or other parties in the form of money, securities, receivables, goods, and other rights that can be valued with money, including state assets that are separated from state / regional companies. One form of state wealth managed by other parties is in the form of social grants and assistance provided by the government to the community;

8. A wealth of other parties controlled by the government in the context of carrying out governmental duties and / or public interests. The wealth of other parties stipulated in this Law does not constitute state money but becomes part of state finances;

9. A wealth of other parties obtained by using facilities provided by the government. The other party's wealth in question is including assets managed by other people or entities based on government policy, foundations within the ministry of state/institution, or state

Intern. Mewujudkan Indonesia Bebas Dari Korupsi. (Yogyakarta: BPFE, 2015), p. 91-92

31 Id., p. 92-93 
/ regional company. The wealth of the other party referred to in this term does not mean that the other party's wealth is automatically part of the property of the state, but the wealth of other parties obtained using facilities provided by the government must be managed and accounted for based on governance principles state finances.

The definition of state finance in the State Finance Act is different from the definition in Act Number 31 the Year 1999 on Corruption Crimes. The Corruption Crime Act states that state finances are all state assets in whatever form are separated or are not separated including all forms of state assets and all rights and obligations arising from $^{32}$ :

1. Being in control, management, and accountability of state agency officials, both at the central and regional levels;

2. Being in control, management, and accountability of the State-Owned Public Entity / Regional-Owned Public Entity, foundations, legal entities and companies that include state capital, or companies that include third-party capital based on state agreements.

Even though the definition of state finance in the two Laws looks different, actually both have similarities. These equations include:

1. Both of these laws regulate the rights and obligations of the state. The intended state right is in the form of state revenue in the form of the right to collect taxes and the state's obligation to pay third party bills (the Law on State Finance). The rights and obligations of the state to collect taxes and pay third party bills are the rights and obligations that are in the possession, management, and accountability of state agency officials (Corruption Crime Act). The state's property which is in the possession, management, and accountability of state agency officials, both at the central and regional levels (the Corruption Act). State's assets separated in-state companies / regional companies (Law on State Finance) are state's assets under the control, management, and accountability of State-Owned Public Bodies and Regionally-Owned Public Bodies (Corruption Crime Act).

2. State assets managed by other people or bodies based on government policy, foundations within the state ministry/institution (Corruption Crimes Act) which obtained using facilities provided by the government (Law on State Finance).

Article 65 paragraph (3) of Act Number 12 the Year 2012 on Higher Education states that Legal Entity State University as referred to in paragraph (1) possesses:

1. Initial assets in the form of separated state's assets other than land;

2. Independent governance and decision making process;

3. Units that carry out the functions of accountability and transparency;

4. The right to manage funds independently, transparently, and accountably;

5. The authority to appoint and dismiss Lecturers and educational staff by themselves;

6. The authority to establish a business entity and develop an endowment; and

${ }^{32}$ Id., p. 94 
7. Authority to offer, organize, and close Study Programs.

Point an of the article states that the initial assets owned by state legal entities are state separated assets other than land. Regarding exempted land, it is regulated in Article 19 paragraph (3) Government Regulation Number 26 in 2015 on the Form and Mechanism of Funding for Legal Entity State University, which states that "Assets in the form of land under the control of Legal Entity State University are obtained from the revenue budget and state expenditure is state's property." Furthermore, in paragraph (6), it is stated that "The results of asset management as referred to in paragraph (2) are sources of Legal Entity State University's revenue.”

A Legal Entity established by the Government with the status of separated state assets implies that since the separation of part of the State's assets into Legal Entity assets, there has been a juridical transformation of public finances into private finances that are fully subject to civil law. ${ }^{33}$ State capital participation in a corporation's status is an ordinary investment with the same legal status as an investment by another party. The purpose of the separation is to make a clear demarcation between public responsibility and corporate responsibility. ${ }^{34}$

Related to state finances, the Constitutional Court in the Decision of the Constitutional Court Number 48 / PUUXI / 2013 states that State-Owned Legal Entities of Higher Education (the terminology of Legal Entity State University), state-owned enterprises (BUMN), regional owned

33 Arifin P. Soeria Atmadja, Mekanisme Pengelolaan Keuangan Negara Indonesia: Suatu Tinjauan Yuridis, (Jakarta: Gramedia, 1985) in Legal Analysis and Evaluation Team on the Traffic of Foreign Exchange and Exchange enterprises (BUMD), or another name, or more specifically, which carries out constitutional mandate in Article 31, Article 32, and Article 33 of the 1945 Constitution is as an extension of the state in carrying out part of the functions of the state to achieve the objectives of the state, namely to educate the life of the nation, or advance the general welfare. Therefore, from the perspective of a legal entity's capital, or another similar name, which carries out part of the function of the state, the financial capital which is partly or wholly comes from state finance. From this perspective and the function of the intended legal entity cannot be fully considered as a private legal entity.

Regarding the constitutional provisions, the Court has interpreted the Court Decision Number 103 / PUU-X / 2012, dated December 12, 2013, in which the Court considered, among others, "According to the Court, although Legal Entity State University is a legal entity, but as reflected in the a quo Law, Legal Entity State University is not entirely the same as a legal entity in the concept of civil law. If a legal entity in the concept of civil law is a truly autonomous and independent entity that is only subject to the provisions of the Act and its internal regulations, then Legal Entity State University in addition is an autonomous entity, but also a public legal entity that is obliged to carry out its duties and responsibilities responsible for the state in the administration of education in higher education institutions. This means that Legal Entity State University is a state agency that is still under state's control in

Value System, Report by Legal Analysis and Evaluation Team on the Traffic of Foreign Exchange and Exchange Value System, (Jakarta, National Legal Coaching Agency, 2009), p. 55 34 Id. 
terms of funding and financing, even though Legal Entity State University is a legal entity, the state is still required to allocate funds for operations, lecturers, and education personnel, as well as investment, and development, also financial support for the administration of higher education [vide Article 89 paragraph (1) and (2) of Act 12/2012]. As a form of state control over the cost of education borne by students, the Government establishes a standard unit of operational costs for higher education periodically used as a basis by state universities to determine the costs borne by students [vide Article 88 paragraph (1) and paragraph (3) Act 12/2012]." [Vide Court Decision, Number 103 / PUU-X / 2012, dated 12 December 2013, paragraph [3.16], pages 215-217];

However, it should also be considered that the provisions of private law also apply to Legal Entity State University's business units, so their management must be following the management of business law. Management of business law is subject to the rules of good business management (good corporate governance) such as the principle of prudence, accountability, transparency, and responsiveness. Business Managers are equipped with fiduciary duties (caring, ability, and honesty), the duty of care (prudence to avoid negligence), and duties to obey statutory duties. Other important doctrines are business judgment rulings teaches that the directors (management) of a corporation is not responsible for losses arising from an act of decision making if the action is based on good faith and prudence. ${ }^{35}$

35 Legal Analysis and Evaluation Team on the Traffic of Foreign Exchange and Exchange Value System, Report by Legal Analysis and Evaluation Team on the Traffic of Foreign
State Enterprises (BUMN) or other Legal Entity established for business interests in its operations is subject to the mindset of civil logic. The civil logic referred to among other things is that business contracts are valid as a law for the parties, good faith is considered to exist among the parties until proven otherwise, and if a promised achievement cannot be fulfilled, it will be subject to default with various alternatives to fulfil it. Business logic is prudence, partnership, cooperation, and collaboration. For example, a business partner that has difficulty making payments and is in debt, the settlement can be in the form of delays in debt payment obligations, hair cut (partial repayment), conversion of debt to equity participation, and so on. If there is a business dispute, the solution is attempted by mediation, and at the most, with arbitration as an alternative dispute resolution that provides a win-win solution. Criminal solutions in business law are only a last resort (ultimum remedium) that will not be taken if not forced. ${ }^{36}$

The above explanation does not mean that Legal Entity State University's business units will be free and immune from criminal liability and prosecution. Criminal offences still threaten Legal Entity State University that brings losses to the businesses they manage. But it must be seen if the cause is purely criminal, such as fraud, bribery, acts that exceed the authority, and other corporate crimes or not. However, if the Legal Entity State University have worked carefully, with careful business considerations (which could be the results deviated from what was expected), good faith, and in the corridor of good merchant

Exchange and Exchange Value System, (Jakarta, National Legal Coaching Agency, 2009)

36 Id., p. 58 
habits (lex mercantoria), which are not against the law, then basically Legal Entity State University must be protected and have immunity like diplomatic immunity or parliamentary immunity in carrying out its duties.

From the explanation above, it can be concluded that not every business loss that arises (business loss) is classified as a state loss. If the occurrences of state financial losses are not caused by intentional acts against the law or abuse of authority, then these are not classified as state losses.

\section{Responsibility for Losses Caused by Legal Entity State University's Business Unit's Activity}

In the previous section, it was concluded that not every arising business loss is classified as a state loss. If the occurrence of state financial losses that occur are not caused by intentional acts against the law or abuse of authority, then these are not classified as state losses.

The provisions of private law also apply to enterprises owned by Legal Entity State University. The implication is, the management of Legal Entity State University must be following with the management of business law. Management of business law is subject to the rules of good business management (good corporate governance) such as the principle of prudence, accountability, transparency, and responsiveness. Business Managers are equipped with fiduciary duties (caring, ability, and honesty), the duty of care (caution to avoid negligence), and duties to obey statutory duties. Other important doctrines are business judgment rules. which teaches that the directors

37 Legal Analysis and Evaluation Team on the Traffic of Foreign Exchange and Exchange Value System, Report by Legal Analysis and (management) of a corporation is not responsible for losses arising from an act of decision making if the action is based on good faith and prudence. ${ }^{37}$

The business judgment rule doctrine does not apply if a violation of the provisions of Private law is found. If so, then Legal Entity State University can be held liable for the loss. About the management of state finances, the injured party, which in this case is the state, can take 3 (three) laws to hold them to account, i.e. the Criminal, Civil, or State Administration laws.

\section{a. Criminal Liability}

Accountability through criminal path must go through a criminal justice process. Criminal Justice is a process in which several law enforcement agencies and their officials work together. Criminal justice activity is a gradual activity starting from the investigation, prosecution, examination at the trial, and ends with the implementation of the decision by the judicial institution. This activity is a series of integrated activities between the Police, Attorney General's Office, the Corruption Eradication Commission, and the Judiciary (Judge), as well as correctional officers, so that this criminal justice can be said to be a system known as the criminal justice system. This means that liability through criminal path is carried out in an integrated and continuous manner, from the confiscation of assets of the perpetrators, together with the threat of imprisonment, so that if the criminal verdict is severed, all assets belonging to the perpetrator will be confiscated and sold to be reimbursed to the State's treasury.

Evaluation Team on the Traffic of Foreign Exchange and Exchange Value System, (Jakarta, National Legal Coaching Agency, 2009), p. 
Based on the provisions of Article 2 paragraph (1) and Article 3 of Act Number 31 of 1999 juncto Act Article 20 of 2001, those included in the elements of criminal acts of corruption include:

1. Everyone, including corporations;

2. Committing acts against the law;

3. Enrich him/herself; and

4. Detrimental to the country's finances.

Article 2 paragraph (1) of Act Number 31 the Year 1999 juncto Act Number 20 the Year 2001 states that:

"Everyone who unlawfully commits acts of enriching oneself or another person or a corporation that can harm the country's finances or the country's economy ..."

Article 3 of Act Number 31 the Year 1999 juncto Act Number 20 the Year 2001 states that:

"Anyone who aims to benefit himself or someone else or a corporation, misuse the authority, opportunity, or means available to him because of his position or authority that can harm the country's finances or the country's economy ..."

The legal sanctions that can be imposed on perpetrators of corruption are in the form of imprisonment and fines (regulated in Article 5, Article 6, Article 7, Article 8, Article 9, Article 10, Article 11, Article 12A, Article 12B, and Article 12C of Act Number 31 the Year 1991 in conjunction with Act Number 20 the Year 2001). ${ }^{38}$

\section{b. Civil Liability}

Indonesian BW (Burgerlijk Wetboek / Code of Civil Law) insists that every act that violates the law, which brings harm to others, obliges the person who because of his mistake that issue the loss, compensates for the loss (Article 1365). Everyone is responsible not only for losses caused by his actions but also for losses caused by negligence or carelessness (Article 1366).

This "Acts against the Law" is intended, of course, not only to individuals but also Legal Entities, so that individuals and Legal Entities can be held accountable by the State when carrying out activities or actions in the management of state finances which are detrimental to the state.

The state as the injured party can file a claim for compensation through a civil suit to the District Court. The lawsuit that applies, in this case, is the same as the lawsuit in general. The state is filing a lawsuit is represented by the State Attorney.

Law Number 31 the Year 1999 in conjunction with Act Number 20 the Year 2001 on Eradication of Corruption Acts regulates strictly the use of civil instruments, among others, in Articles 32, 33, 34, of Act Number31 the Year 1999, and Article $38 \mathrm{C}$ of Act Number 20 the Year 2001.

Civil case, that arises related to corruption cases with the use of civil instruments as regulated in Article 32 paragraph (1) of Act Number 31 the Year 1999, is that if an investigator handles a case that has clearly had a state financial loss, but there is not enough evidence to prove the criminal elements of corruption, then the investigator stops the investigation. In this case, the investigator submits the case file of the results of his investigation to the State Attorney or the aggrieved agency, to make a civil suit against the former suspect who

38 Aziz Syamsuddin, Tindak Pidana Khusus (Jakarta: Sinar Grafika, 2011), p. 17 
has harmed the state's finances. Some reasons for the use of civil law instruments in-state losses are first, following Article 33 and Article 34 of Act Number 31 the Year 1999 wherein the investigation of corruption cases there is a possibility of the death of the suspect, whereas there has been a state financial loss. The investigation had to be stopped and the investigator handed over the results of his investigation to the State Attorney or the aggrieved agency, to make a civil suit against the heirs of the suspect. If the Defendant dies during an examination at a court hearing, while the loss in the state's finance is real, then the public prosecutor submits a copy of the minutes of proceedings to the State Attorney or the injured institution for a civil suit against the defendant's heir. Second, Article 38 C of Law Number 20 of 2001 that after the court's decision obtained permanent legal force, it is known that there are still assets belonging to corrupt convicts who have not been subject to seizure (while in court the defendant cannot prove that the assets were obtained not by mean of corruption), then the state can make a civil suit against the convicted and/or his/her heirs. In this case, the aggrieved agency may authorize the State Attorney or its legal counsel to represent it.

The use of civil law instruments, in fact, has not been carried out this much because of many obstacles, such as the settlement time to completely solve the case by a court decision that has legal force can take quite a long time (years). For this reason, the Law on Corruption requires that the examination of corruption crimes cases be given priority, while civil lawsuits relating to corruption cases are not so

39 Hendra Karianga, Pertanggungjawaban Kerugian Negara dalam Pengelolaan Keuangan prioritized. Another obstacle is that there is a possibility that the defendant will sue the state and there is a possibility that the State will lose so that the State must compensate the plaintiff if the State loses. ${ }^{39}$

\section{c. Accountability in State Administrative}

One element of the existence of a criminal act of corruption committed by an individual or legal entity is that the committed act can be detrimental to the State's finances or the State's economy (Article 2 paragraph (1) juncto Article 3 of Law Number 20 of 2001), whereas what is meant by State's financial loss is the amount of losses that can be calculated based on the findings of the authorized agency, which can come from the Supreme Audit Agency (BPK), the National Audit and Development Inspection Agency (BPKP), and the Inspectorate at the central or regional level, or a designated public accountant.

The occurrence of state losses in this case certainly gives authority to the State to be able to hold accountable not to the perpetrators of corruption directly, but from the official in charge of managing finances. The Act Number 17 the Year 2003 on State Finance, in its explanation, states that those who are authorized to receive, keep, and paid or hand over money, valued letters, or State property are personally responsible for all deficiencies that occur in their administration.

In connection with this responsibility in finances, Law Number 1 the Year 2004 on the State Treasury regulates the issue in Article 53 paragraphs 1 to 4 and Article 54 paragraphs 1 and 2 .

Daerah, (Jurnal Pendidikan, Volume 16, No 1, January 2018), p. 40-41

252 | Hadiyantina, Ramadhan - State Regulation on Business Entities Owned by State Universities... 
Therefore, the responsibility for returning the compensation of state finances as determined is to avoid the occurrence of state losses due to unlawful acts, either on purpose or due to negligence of an official, so that the guilty party who has caused state financial losses must replace them to ensure the state finances recover from the loss caused by the abuse of power.

As a result of the abuse of power or authority (exes depavoir) which causes acts of corruption, the loss to state finances is significant. That is why the Law requires that leaders of State ministries or institutions and heads of regional work units immediately make claims for state compensation after knowing that their institutions have been disadvantaged through two means. The first is Compensation Claims (TGR) to Civil Servants rather than to treasurers/other officials who for committing acts against the law, both intentionally or negligently, resulting in State losses, not in the form of a lack of treasury, and the competency of burdening lies with the Minister or Head of the concerned Institution. Second, the Treasury Claims (TP) imposed on the Treasurer as a result of unlawful acts, both by intentional or negligent, that have resulted in treasury deficiencies, where the competence of burdening the compensation lies on the BPK. ${ }^{40}$

\section{CONCLUSION SUGGESTION}

AND

The loss experienced by business entities owned by Legal Entity State University can be categorized as state losses if the losses occur due to intentional or unlawful acts. If the loss is caused purely by a business loss, it cannot be categorized as a state loss.

In the other hand, liability for damages caused by the activities of the Legal Entity State University's business unit can be carried out in three ways, namely criminal liability, civil liability, and accountability in the state administration.

\section{REFERENCES}

\section{Book}

Ardeno Kurniawan, Korupsi di Indonesia: Keuangan Negara, Birokrasi dan Pengendalian Intern. Mewujudkan Indonesia Bebas Dari Korupsi (Yogyakarta: BPFE, 2015)

Arifin P. Soeria Atmadja, Mekanisme Pengelolaan Keuangan Negara Indonesia: Suatu Tinjauan Yuridis (Jakarta: Gramedia, 1985)

Aziz Syamsuddin, Tindak Pidana Khusus (Jakarta: Sinar Grafika, 2011)

Eugenio M. Gonzales, Membentuk dan Mengelola Dana Abadi: Pelajaran dari Asia Tenggara (Jakarta: Lembaga Penelitian, Pendidikan, dan Penerangan Ekonomi dan Sosial (LP3ES), 2004)

Jimly Asshiddiqie, Konstitusi Bernegara: Praksis Kenegaraan Bermartabat dan Demokratis (Malang: Setara Press, 2015)

Mohammad Faisal Amir, Manajemen Kinerja Perguruan Tinggi (Jakarta: Mitra Wacana Media, 2016)

Philipus M. Hadjon dkk., Pengantar Hukum Administrasi Indonesia (Introduction to The Indonesian Administrative Law) (Yogyakarta: Gadjah Mada University Press, 2008)

${ }^{40}$ Id., p. 41-43. 
Ridwan, Tiga Dimensi Hukum Administrasi dan Peradilan Administrasi, (Yogyakarta: FH UII Press, 2009)

Serian Wijatno, Pengelolaan Perguruan Tinggi Secara Efisien, Efektif, dan Ekonomis: Untuk Meningkatkan Mutu Penyelenggaraan Pendidikan dan Mutu Lulusan (Jakarta: Penerbit Salemba Empat, 2009)

Tim Analisa dan Evaluasi Hukum tentang Lalulintas Devisa dan Sistem Nilai Tukar, Laporan Tim Analisa dan Evaluasi Hukum tentang Lalulintas Devisa dan Sistem Nilai Tukar (Jakarta: Badan Pembinaan Hukum Nasional, 2009)

\section{Journal}

Hendra Karianga, Pertanggungjawaban Kerugian Negara dalam Pengelolaan Keuangan Daerah, Jurnal Pendidikan, Volume 16, No 1, Januri 2018

Muhammad Rakhmat, 2014, Hukum Administrasi Negara Indonesia, Jurnal Universitas Majalengka, dari jurnal.unma.ac.id/index.php/RBJ/arti cle/download/531/495

\section{Acts}

Undang-Undang Dasar Negara Republik Indonesia Tahun 1945

Undang-Undang Nomor 20 Tahun 2013 tentang Sistem Pendidikan Nasional (Lembaran Negara Tahun 2013 Nomor 132, Tambahan Lembaran Negara Republik Indonesia Nomor 4301)

Undang-Undang Nomor 12 Tahun 2012 tentang Pendidikan Tinggi (Lembaran Negara Tahun 2012 Nomor 158, Tambahan Lembaran Negara Republik Indonesia Nomor 5336)
Peraturan Pemerintah Nomor 26 Tahun 2015 tentang Bentuk dan Mekanisme Pendanaan Perguruan Tinggi Negeri Badan Hukum (Lembaran Negara Tahun 2015 Nomor 110, Tambahan Lembaran Negara Republik Indonesia Nomor 5699)

Peraturan Pemerintah Nomor 4 Tahun 2014 tentang Penyelenggaraan Pendidikan Tinggi dan Pengelolaan Perguruan Tinggi (Lembaran Negara Tahun 2014 Nomor 16, Tambahan Lembaran Negara Republik Indonesia Nomor 5500)

\section{Internet Materials}

Berita Web Dikti, 11 PTN-BH Didorong Meningkatkan Penelitian dan Inovasi, Koordinasi Perguruan Tinggi Swasta Wilayah XII (4 Januari 2017) <http://www.kopertis12.or.id/2017/0 1/05/12-ptn-bh-didorongmeningkatkan-penelitian-daninovasi.html>

Dny, MK Batalkan UU Badan Hukum Pendidikan, Hukum Online (31 Maret 2010) <http://www.hukumonline.com/berit a/baca/lt4bb37a39de6cc/mkbatalkan-uu-badan-hukumpendidikan>

Universitas Indonesia, Dana Abadi $<$ https://www.ui.ac.id/berandaalumni/dana-abadi.html> 